\begin{tabular}{|l|l|l|}
\hline \multicolumn{2}{|c|}{ PublisherInfo } \\
\hline \hline PublisherName & $:$ & BioMed Central \\
\hline \hline PublisherLocation & $:$ & London \\
\hline \hline PublisherImprintName & $:$ & BioMed Central \\
\hline \hline
\end{tabular}

\title{
Database of publicly available nucleotide sequences
}

\begin{tabular}{|l|l|l||}
\hline \multicolumn{2}{|c|}{ ArticleInfo } \\
\hline \hline ArticleID & $:$ & 3591 \\
\hline \hline ArticleDOI & $:$ & $10.1186 /$ gb-2000-1-1-reports217 \\
\hline \hline ArticleCitationID & $:$ & reports217 \\
\hline \hline ArticleSequenceNumber & $:$ & 82 \\
\hline \hline ArticleCategory & $:$ & Web report \\
\hline \hline ArticleFirstPage & $:$ & 1 \\
\hline \hline ArticleLastPage & $:$ & 4 \\
\hline \hline & & RegistrationDate : 1999-11-12 \\
ArticleHistory & $:$ & Received \\
\hline \hline ArticleCopyright & $:$ & BioMed Central Ltd2000-11-12 \\
\hline \hline ArticleGrants & $:$ & \\
\hline \hline ArticleContext & $:$ & 130591111 \\
\hline \hline
\end{tabular}




\section{Abstract}

Publicly available nucleotide sequences, along with their associated annotations are available here.

\section{Content}

Publicly available nucleotide sequences, along with their associated annotations are available here. The data mostly come from the International Nucleotide Sequence Database Collaboration, made up of the European Bioinformatics Institute (responsible for the EMBL nucleotide sequence database), the National Center for Biotechnology Information (responsible for GenBank), and the DNA Databank of Japan. The members of this collaboration share their data on a daily basis. The GSDB compliments the data with additional tools for sequence searching and viewing. These data are searchable using BLAST sequence alignment programs (although the link was broken when I tried the site), a sequence retriever and viewer (programmed in Java), and more straightforward searches can be carried out, for example according to chromosome, organism and author. The different searches are interlinked, allowing the results of searches to be viewed easily in several different formats. Registration is required for use of the Java sequence viewer, but this is easy and free.

\section{Navigation}

Navigation was easy but it was sometimes unclear which of a variety of options was relevant to the problem in hand. The site may therefore require some getting used to but should prove useful with more experience.

\section{Reporter's comments}

\section{Timeliness}


This site is updated daily.

\section{Best feature}

There are several methods for searching the database.

\section{Worst feature}

The most powerful sequence retrieval and viewing tool on the site requires a Java plug-in program that appears to be available only for Windows 95/NT and Solaris (that is, not for the SGI that the site was reviewed on).

\section{Wish list}

A sequence viewer that runs on a wider variety of platforms would be useful.

\section{Related websites}

Nucleotide sequences are available from EMBL nucleotide sequence database database, GenBank and the DNA Databank of Japan.

\section{Table of links}

The Genome Sequence Database (GSDB)

EMBL nucleotide sequence database

GenBank

DNA Databank of Japan 


\section{References}

1. The Genome Sequence Database (GSDB).

This PDF file was created after publication. 